\title{
Pars plana vitrectomy and silicone oil tamponade for acute endophthalmitis treatment
}

\author{
Vitrectomia pars plana e tamponamento por óleo de silicone para o \\ tratamento de endoftalmite aguda
}

\author{
Rubens Camargosiqueira ${ }^{1}$ \\ Aline Degasperi Cote Gil² \\ Fabio Canamary ${ }^{3}$ \\ Mirian Minari ${ }^{4}$ \\ Rodrigo Jorg' $\mathbf{e}^{5}$
}

Trabalho realizado no Centro de Pesquisa Rubens Siqueira de São José do Rio Preto (SP) - Brasil, no Hospital do Olho de Rio Preto - São José do Rio Preto (SP)

e Universidade de São Paulo - USP - Ribeirão Preto (SP) - Brasil.

${ }^{1}$ Responsável pelo Centro de Pesquisa Rubens Siqueira - CPRS - de São José do Rio Preto (SP) - Brasil, Médico colaborador em pesquisa da Universidade de São Paulo - USP - Ribeirão Preto (SP) - Brasil. Responsável pelo Departamento de Oftalmologia da Faculdade de Medicina de Catanduva - Catanduva (SP) - Brasil.

${ }^{2}$ Médico assistente do CPRS de São José do Rio Preto (SP) - Brasil.

${ }^{3}$ Fellow de retina do CPRS de José do Rio Preto (SP) Brasil.

${ }^{4}$ Residente em Oftalmologia do Hospital do Olho de São José do Rio Preto (SP) - Brasil.

${ }^{5}$ Responsável pelo Departamento de Retina e Vítreo da USP - Ribeirão Preto (SP) - Brasil.

Corresponding author: Rubens Camargo Siqueira. Rua Saldanha Marinho, 2.815 - Conj. 42 - São José do Rio Preto (SP) Code 15010-100

E-mail: rubenssiqueira@terra.com.br

Recebido para publicação em 07.06.2007

Última versão recebida em 09.12.2008

Aprovação em 11.12.2008

\begin{tabular}{l} 
ABSTRACT \\
\hline Purpose: To evaluate the outcomes of pars plana vitrectomy and silicone \\
oil injection for the treatment of infectious endophthalmitis. Methods: 35 \\
cases of endophthalmitis secondary to phacoemulsification (20 patients), \\
trabeculectomy ( 8 patients), perforating trauma (2 patients), trauma ( \\
patients), corneal transplantation (1 patient), vitrectomy (1 patient) and \\
corneal ulceration (1 patient) were retrospectively studied. Patients were \\
separated into two groups: Group 1 (n=24): intravitreal antibiotic injection, \\
associated with topical and oral antibiotics; Group 2 (n=11): vitrectomy \\
with intravitreal antibiotic injection and silicone oil injection. The follow- \\
up ranged from 1 to 48 months (mean of 16 months). Results: From 24 \\
patients in group 1,11 patients ( $45.83 \%)$, had infection controlled with \\
intravitreal antibiotic injection only; 13 patients (54.15\%) regressed to \\
uncontrolled endophthalmitis, in which two patients (8.33\%) were \\
submitted to evisceration and one patient (4.16\%) had corneal melting. \\
The remaining 10 patients (41.66\%) with uncontrolled endophthalmitis \\
were submitted to pars plana vitrectomy and silicone oil injection. Six \\
patients (25\%) from Group I had retinal detachment during the first month \\
of follow-up and also required pars plana vitrectomy and silicone oil \\
injection. In Group 2 patients (n=11), all of them had controlled infection \\
at the first procedure. In one case (9.09\%), a severe proliferatative vitreo- \\
retinopathy induced loss of vision. Conclusion: These results suggest \\
that silicone oil tamponade might be beneficial in the treatment strategy \\
of infectious endophthalmitis.
\end{tabular}

Keywords: Vitrectomy; Silicone oils; Endophthalmitis

\section{INTRODUCTION}

Endophthalmitis is most commonly reported after cataract surgery but may occur after any intraocular procedure, after trauma, or from endogenous sources. The incidence of endophthalmitis after cataract surgery varies according to the surgical technique, but in recent large series, it has ranged from $0.04 \%$ to $0.13 \%{ }^{(1-4)}$. Endophthalmitis after filtering surgery is probably the second most commonly encountered etiologic category. Because of its typically delayed onset, the exact incidence is more difficult to ascertain. With longer follow-up, bleb-associated endophthalmitis may occur in at least $1 \%$ of patients and has been described in up to $1.7 \%$ of eyes per year when antimetabolites are used ${ }^{(2,5-6)}$. This incidence of endophthalmitis is even higher when the bleb is constructed inferiorly ${ }^{(5-6)}$. The treatment of endophthalmitis has historically involved 
multiple routes of antibiotic administration, including intravitreal, systemic, topical, and subconjunctival ${ }^{(7)}$. With the advent of pars plana vitrectomy techniques, vitrectomy combined with injection of intravitreal antibiotics became the standard treatment for virtually all forms of endophthalmitis $^{(8-9)}$. Favorable sensitivity profiles and acceptably low toxicity rates have resulted in vancomycin and ceftazidime (more recently supplanting aminoglycosides) becoming a widely utilized regimen of intravitreal antibiotics ${ }^{(10-12)}$. Topical and subconjunctival antibiotics are also commonly used.

The role of pars plana vitrectomy (PPV) in the treatment of endophthalmitis is controversial. The results of the Endophthalmitis Vitrectomy Study (EVS) suggested that patients, with a visual acuity of light perception, have better prognosis if treated with immediate $\mathrm{PPV}^{(13)}$. Silicone oil has been used increasingly in vitreoretinal surgery as an internal tamponade, with a significant improvement of the anatomical and visual outcome in many bad prognosis cases ${ }^{(14)}$. The dynamics of silicone involve surface tension and viscosity, but also limit the free movements of aqueous humor in the eye. No microorganisms seem to be able to penetrate and develop within this inert material ${ }^{(15)}$. Moreover, antibacterial properties of silicone oil have been recently reported in vitro ${ }^{(16)}$. Since the early nineties, vitreoretinal surgeons have used silicone oil in some cases of endophthalmitis with extensive retinal damage as intraocular tamponade in order to prevent retinal detachment ${ }^{(16-21)}$.

The purpose of this retrospective study was to compare the results of treating endophthalmitis using 3 options: 1) intravitreal antibiotic injection (IVAB) 2) vitrectomy with injection of silicone oil and antibiotics as a first treatment 3) vitrectomy with injection of silicone oil and antibiotics as a second treatment after the failure of IVAB.

\section{METHODS}

Thirty-five charts from thirty-five patients with endophthalmitis treated at HORP-Hospital do Olho de Rio Preto-São Paulo-Brazil, between January 2001 and 2006 were reviewed.

The clinical diagnosis was based on the standard sign and symptoms of endophthalmitis: pain, loss of vision, lid edema, conjunctival chemosis and injection, corneal edema, anterior chamber flare, hypopyon, and vitreous opacification. Culture studies of vitreous samples were performed in all cases.

The patients were separated into two groups:

Group 1 (24 patients): Intravitreal antibiotic injection (IVAB), vancomycin $1 \mathrm{mg} / 0.1 \mathrm{ml}$, ceftazidime $2.25 \mathrm{mg} / 0.1 \mathrm{ml}$, dexamethasone $0.4 \mathrm{mg} / 0.1 \mathrm{ml}$ ). Periocular (subconjunctival) vancomycin $25 \mathrm{mg}$, ceftazidime $100 \mathrm{mg}$, dexamethasone 12 to $24 \mathrm{mg}$. Topical (started on first postoperative day) vancomycin $50 \mathrm{mg} / \mathrm{ml} \mathrm{q} 1$ hour, ceftazidime $50 \mathrm{mg} / \mathrm{ml} \mathrm{q} 1$ hour. Topical steroids and cycloplegics. Systemic: vancomycin $1 \mathrm{~g}$ IV q 12 hours, ceftazidime $1 \mathrm{~g}$ IV q 12 hours or ciprofloxacin $750 \mathrm{mg}$ p.o. q 12 hours for susceptible organisms.
Group 2 (11 patients): Pars plana vitrectomy (PPV) with injection of silicone oil (SOI) and antibiotics as a first treatment. The patients were submitted to standard three-port pars plana vitrectomy using ACCURS vitrectomy machine (Alcon, Fort Worth, Texas, USA). Initially, the central vitreous was removed (core vitrectomy), with later peeling of dense epiretinal membranes. Next, the remaining traction points were identified; including those of hard removal, i.e., star folds with intraretinal fibrosis. At those sites, instead of removing membranes with the use of forceps, a puncture retinotomy was performed using endodiathermy. After relaxing the traction areas, subretinal fluid was aspirated with a long extensible silicone-tipped cannula, taking advantage of the retinotomy. After this procedure, we checked whether the entire retina was attached and, if this was not the case, additional retinotomies were made to release the traction, and a new aspiration of subretinal fluid was performed. After the retina was entirely flattened against the retinal pigment epithelium RPE, photocoagulation was applied surrounding all retinal breaks and along the entire edge of the puncture retinotomies. At the end of the procedure silicone oil was injected into the eye with IVAB.

The follow-up ranged from 1 to 48 months (mean=16 months). Anatomical status and visual outcome were recorded in order to compare the prognosis of different approaches.

The criteria for control of infection were: a) absorption of hypopyon, b) decrease or absence of cells and flare in the anterior chamber and vitreous, c) improvement of symptoms such as pain, d) improvement in congestion and conjunctival hyperemia and eyelids.

\section{RESULTS}

Clinical characteristics of all patients are shown in tables 1 and 2.

The average age of the patients was 66.82 years (range, 12-85 years). A vitreous positive culture was found in 12 cases (34.28\%). Of these 12 cases, $6(50 \%)$ were due to Staphylococcus epidermidis: 2 (16.66\%) cases were due to Streptococcus sp; 1 case each was due to Staphylococcus saprofiticus, Staphylococcus aureus and Morganella morganii.

In Group 1, the average visual acuity ranged from 20/30 to light perception (before treatment) and 20/60 to light perception (after treatment). Nine patients (37.5\%) had worsening of visual acuity, 10 patients (41.6\%) improved and 5 patients $(20.83 \%)$ did not change.

In Group 2, the average visual acuity ranged from 20/40 to light perception (before treatment) and 20/30 to light perception (after treatment). One patient $(9.09 \%)$ showed worsening of visual acuity, 5 patients (45.45\%) improved and 5 patients $(45.45 \%)$ did not change.

From 24 patients in Group 1, 11 (45.83\%), had infection control with IVAB only; 13 patients $(54.15 \%)$ progressed to 


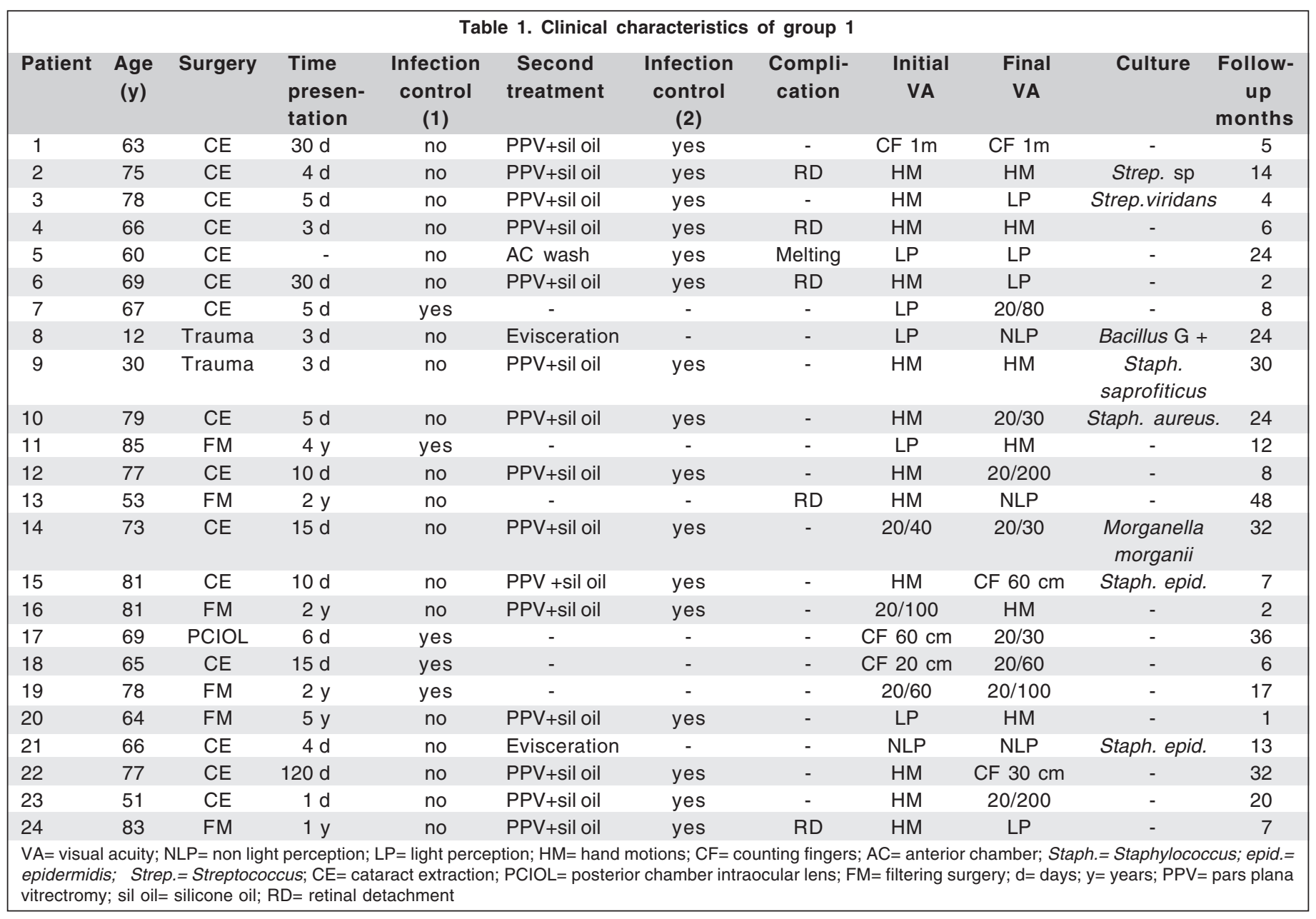

\begin{tabular}{|c|c|c|c|c|c|c|c|}
\hline Patient & $\begin{array}{c}\text { Age } \\
\text { (years) }\end{array}$ & Surgery & Presentation & $\begin{array}{c}\text { Initial } \\
\text { VA }\end{array}$ & $\begin{array}{c}\text { Final } \\
\text { VA }\end{array}$ & Culture & $\begin{array}{c}\text { Follow-up } \\
\text { months }\end{array}$ \\
\hline 25 & 79 & CE & 4 days & $\mathrm{HM}$ & $20 / 60$ & - & 12 \\
\hline 27 & 62 & CE & 5 days & NLP & NLP & - & 48 \\
\hline 28 & 73 & FM & 1 year & $\mathrm{HM}$ & NLP & Staph. epid. & 48 \\
\hline 31 & 71 & $\mathrm{CE}$ & 8 days & $\mathrm{HM}$ & $\mathrm{HM}$ & - & 5 \\
\hline 32 & 57 & $\mathrm{CE}$ & 10 days & LP & CF $60 \mathrm{~cm}$ & - & 7 \\
\hline 33 & 56 & Fungal keratitis & 60 days & LP & LP & - & 12 \\
\hline 34 & 66 & CE & 6 days & HM & $\mathrm{HM}$ & Staph. epid. & 6 \\
\hline 35 & 62 & CE & 3 years & CF $1 \mathrm{~m}$ & $20 / 400$ & Staph. epid. & 2 \\
\hline
\end{tabular}

uncontrolled endophthalmitis, in which two patients $(8.33 \%)$ were submitted to evisceration and one patient $(4.16 \%)$ had corneal melting. The remaining 10 patients $(41.66 \%)$ with uncontrolled endophthalmitis were submitted to PPV and SOI. Six patients $(25 \%)$ from Group I had retinal detachment during the first month of follow-up and also required PPV and SOI. In Group 2 patients $(n=11)$, all of them had controlled infection on the first procedure. In one case $(9.09 \%)$, a severe proliferatative vitreoretinopathy (PVR) induced loss of vision (NLP). 


\section{DISCUSSION}

The relationship between the use of silicone oil and endophthalmitis has been little discussed. Endophthalmitis is considered one of the most devastating complications of ophthalmic surgery. The incidence of endophthalmitis after cataract surgery ranges from 0.04 to $0.13 \%{ }^{(22-25)}$. And after vitrectomy surgery from 0.046 to $0.07 \%{ }^{(12,26)}$. The incidence of endophthalmitis after vitrectomy where silicone oil was used is more rare with only 2 cases reported in the literature with positive culture ${ }^{(3,20)}$. Other authors reported 2 cases of endophthalmitis in patients undergoing surgery with silicone oil, but the culture was negative and because the inflammatory reaction was probably consequent to the components of silicone oil ${ }^{(7-10)}$.

The likely antimicrobial potential of silicone oil has recently been reported. The authors demonstrated in vitro that the silicone oil decreases the proliferation of bacteria responsible for endophthalmitis ${ }^{(18)}$. In the eyes of humans, the action of silicone oil against the microorganisms could be explained by the following mechanisms: 1) the silicone oil can be toxic to the bacteria, as suggested in in vitro experiments, however this hypothesis still needs to be confirmed by more experiments; 2) the silicone oil is highly hydrophobic with a high interfacial tension and thus presents a low permeability to the passage of cells and bacteria ${ }^{(8)}$. Therefore, this limits the space for the movement of infectious agents and keeps them in touch with the ciliary body and vessels of the retina, which can improve the effectiveness of the defense mechanisms, by a high concentration of biochemical mediators, antibodies and inflammatory cells within an aqueous compartment of the vitreous cavity.

In the literature, endophthalmitis is suspected to increase the risk of retinal detachment. EVS reported 20 cases of retinal detachment in a series of 420 patients, 6 in the vitrectomy group (2.8\% of 218 patients) and 14 in the non vitrectomy group ( $6.9 \%$ of 202 patients). Other authors ${ }^{(17)}$ described retinal detachment to occur in $21 \%(7 / 34)$ of endophthalmitis patients treated with vitrectomy and intraocular antibiotics.

In the other study a similar complication rate was described with $26 \%$ retinal detachments (9/34): 8 patients (23\%) in the non silicone groups ( 1 and 2), 1 patient (7\%) in the silicone groups ( 3 and 4 ). The authors postulated that retinal detachment could be either the result of surgical complications or be provoked by the changes in retina and vitreous as a reaction to severe ocular inflammation ${ }^{(21)}$.

Our series showed that in Group 1, 11 patients (45.83\%), had infection control with intravitreal injections only. However, $16(66.66 \%)$ patients required pars plana vitrectomy and silicone oil, 10 patients $(41.66 \%)$ had uncontrolled endophthalmitis and $6(25 \%)$ had retinal detachment. Two patients $(8.33 \%)$ were submitted to evisceration and one patient $(4.16 \%)$ had corneal melting.

In Group 2, all patients had controlled infection at the first procedure and did not need further surgery, except for removal of silicone oil three months later. In one case
(9.09\%), a severe PVR induced loss of vision (NLP) but the cosmetic results were acceptable.

Many authors also reported that concurrent endophthalmitis and retinal detachment have a poor visual and anatomical outcome, especially when retinal detachment is an intraoperative complication $^{(2,11,15,19-20)}$. The use of silicone oil can therefore help in controlling the infectious process and reduce the risk of retinal detachment, contributing to a better outcome in the treatment of endophthalmitis. After control of the infectious and inflammatory process the silicone oil can be removed, which in our study was conducted on average 3 months after the procedure.

\section{CONCLUSION}

This retrospective study suggests that silicone oil might be beneficial in the treatment strategy of severe endophthalmitis. Patients treated with silicone oil have a better control of infection, better anatomical stabilization and better final visual acuity. Additionally, silicone oil seems to reduce the risk of retinal detachment and the need for additional procedures.

The role of silicone oil in the treatment of endophthalmitis should be better assessed by a prospective, controlled study and with the highest number of cases to confirm the evidence of this study.

\section{RESUMO}

Objetivo: Avaliar os resultados da vitrectomia pars plana com tamponamento com óleo de silicone no tratamento de endoftalmite aguda. Métodos: Trinta e cinco pacientes com endoftalmite, sendo 20 secundário à facoemulsificação, 8 por trabeculectomia, 2 por trauma perfurante, 2 por trauma, 1 por transplante de córnea, 1 por vitrectomia, e 1 por úlcera de córnea, foram estudados retrospectivamente. Os pacientes foram separados em dois grupos. Grupo $1(\mathrm{n}=24)$ : injeção de antibiótico intravítreo (AIV), associado com antibióticos oral e sistêmico; Grupo 2 ( $\mathrm{n}=11)$ : vitrectomia com AIV e óleo de silicone. O seguimento variou de 1 a 48 meses (média de 16 meses). Resultados: Dos 24 pacientes no Grupo 1, $11(45,83 \%)$ tiveram controle da infecção apenas com injeção AIV, 13 (54,15\%) não controlaram a endoftalmite, sendo que, dois destes $(8,33 \%)$ foram submetidos à evisceração e um $(4,16 \%)$ evoluiu para "melting" corneano. Os outros $10(41,66 \%)$ pacientes foram submetidos à vitrectomia pars plana e óleo de silicone. Seis pacientes (25\%) do Grupo 1 tiveram descolamento de retina e também necessitaram de vitrectomia pars plana e óleo de silicone. No Grupo $2(\mathrm{n}=11)$, todos tiveram controle da infecção no primeiro procedimento e não necessitaram de mais intervenções, exceto pela remoção do óleo de silicone três meses depois. Conclusão: Os resultados sugerem que o tamponamento por óleo de silicone parece ser benéfico na estratégia de tratamento da endoftalmite infecciosa aguda.

Descritores: Vitrectomia; Óleo de silicone; Endoftalmite 


\section{REFERENCES}

1. Affeldt JC, Flynn HW Jr, Forster RK, Mandelbaum S, Clarkson JG, Jarus D. Microbial endophthalmitis resulting from ocular trauma. Ophthalmology. 1987;94(4):407-13.

2. Brinton GS, Topping TM, Hyndiuk RA, Aaberg TM, Reeser FH, Abrams GW. Posttraumatic endophthalmitis. Arch Ophthalmol. 1984;102(4):547-50.

3. Chong LP, De Juan E Jr, McCuen BW $2^{\text {nd }}$, Landers MB $3^{\text {rd }}$. Endophthalmitis in a silicone oil-filled eye. Am J Ophthalmol.1986;102(5):660-1.

4. Cohen SM, Flynn HW Jr, Murray TG, Smiddy WE. Endophthalmitis after pars plana vitrectomy. The Postvitrectomy Endophalmitis Study Group. Ophthalmology. 1995;102(5):705-12.

5. Results of the Endophthalmitis Vitrectomy Study: A randomized trial of immediate vitrectomy and of intravenous antibiotics for the treatment of postoperative bacterial endophthalmitis. Endophthalmitis vitrectomy Study Group. Arch Ophthalmol. 1995;113(12):1479-96. Comment in: Arch Ophthalmol. 1995;113(12):1555-7; Arch Ophthalmol. 1996;114(8):1025-6; author reply 1026-7; Arch Ophthalmol. 1996;114(8):1025; author reply 1026-7; Arch Ophthalmol. 1996;114(8):1027-8; author reply 1028-9; Arch Ophthalmol. 1996;114(8):1029-30; author reply 1028-9; Arch Ophthalmol. 1996;114(8): 1029; author reply 1028-9, 1030; Arch Ophthalmol. 2002;120(2):230-1; Arch Ophthalmol. 2002;120(2):231-3.

6. Foster RE, Rubsamen PE, Joondeph BC, Flynn HW Jr, Smiddy WS. Concurrent endophthalmitis and retinal detachment. Ophthalmology. 1994;101(3):490-8.

7. Gabel VP, Kampik A, Burkhardt J. Analysis of intraocularly applied silicone oils of various origins. Graefes Arch Clin Exp Ophthalmol. 1987;225(3):160-2.

8. Giordano GG, Refojo MF. Silicone oils as vitreous substitutes. Prog Polym Sci. 1998;23:509-32.

9. Johnson RN, Flynn HW Jr, Parel JM, Portugal LM. Transient hypopyon with marked anterior chamber fibrin following pars plana vitrectomy and silicone oil injection. Arch Ophthalmol. 1989;107(5):683-6. Comment in: Arch Opthalmology. 1989;107(11):1566.

10. Kampik A. Silicone oil interaction with ocular tissue. Int Ophthalmol Clin. 1987;10:85.

11. Kattan HM, Flynn HW Jr, Pflugfelder SC, Robertson C, Forster RK. Nosocomial endophthalmitis survey. Current incidence of infection after intraocular surgery. Ophthalmology. 1991;98(2):227-38. Comment in: Ophthalmology. 1991;98(8):1147-8.

12. Kresloff MS, Castellarin AA, Zarbin MA. Endophthalmitis. Surv Ophthalmol. 1998;43(3):193-224.
13. Landers JH, Chappell CW. Bilateral metastatic endophthalmitis. Retina. 1981;1(3):175-8.

14. Lucke K, Laqua H. Silicone oil in the treatment of complicated retinal detachments. Berliln: Springer-Verlag. 1990.

15. Mao LK, Flynn HW Jr, Miller D, Pflugfelder SC. Endophthalmitis caused by streptococcal species. Arch Ophthalmol. 1992;110(6):798-801.

16. Mieler FW, Glazer LC, Bennett SR, HaN DP. Favourable outcome of traumatic endophthalmitis with associated retinal breaks or detachment. Can J Ophthalmol. 1992;27(7):348-52.

17. Nelsen PT, Marcus DA, Bovino JA. Retinal detachment following endophthalmitis. Ophthalmology. 1985;92(8):1112-7.

18. Ozdamar A, Aras C, Ozturk R, Akin E, Karacorlu M, Ercikan C. In vitro antimicrobial activity of silicone oil against endophthalmitis causing agents. Retina. 1999;19(2):122-6. Comment in: Retina. 2001;21(1):92-3.

19. Vahey JB, Flynn HW Jr. Results in the managementof bacillus endophthalmitis. Ophthalmic Surg. 1991;22(11):681-6. Comment in: Ophthalmic Surg. 1992;23(5):368.

20. Zimmer-Galler IE, Santos A, Haller JA, Campochiaro PA. Management of endophthalmitis in a silicone filled eye. Retina. 1997;17(6):507-9.

21. Bali E, Huyghe PH, Caspers L, Libert J. Vitrectomy and silicone oil in the treatment of acute endophthalmitis. Preliminary results. Bull. Soc Belge Ophtalmol. 2003;(288):9-14.

22. Benz MS, Scott IU, Flynn HW Jr, Unonius N, Miller D. Endophthalmitis isolates and antibiotic sensitivities: A 6-year review of culture-proven cases. Am J Ophthalmol. 2004;137(1):38-42. Comment in: Am J Ophthalmol. 2004; 137(6):1167-8; author reply 1168; Am J Ophthalmol. 2004;137(6):1169; author reply $1169-70$.

23. Schiedler V, Scott IU, Flynn HW Jr, Davis JL, Benz MS, Miller D. Cultureproven endogenous endophthalmitis: clinical features and visual acuity outcomes. Am J Ophthalmol. 2004;137(4):725-31.

24. Miller JJ, Scott IU, Flynn HW Jr., Smiddy WE, Newton J, Miller D. Acuteonset endophthalmitis after cataract surgery (2000-2004): Incidence, clinical settings, and visual acuity outcomes after treatment. Am J Ophthalmol. 2005; 139(6):983-7. Comment in: Am J Ophthalmol. 2005;139(6):1097-8.

25. Miller JJ, Scott IU, Flynn HW Jr, Smiddy WE, Corey RP, Miller D. Endophthalmitis caused by streptococcus pneumoniae. Am J Ophthalmol. 2004; 138(2):231-6. Comment in: Am J Ophthalmol. 2005;139(6):1147; author reply 1147-8.

26. Eifrig CW, Scott IU, Flynn HW Jr, Smiddy WE, Newton J. Endophthalmitis after pars plana vitrectomy: Incidence, causative organisms, and visual acuity outcomes. Am J Ophthalmol. 2004;138(5):799-802. 